\title{
ヘパトカタラーゼによるリノール酸メチルーハイドロ パーオキサイドのペルオキシダーゼ性分解について
}

内 藤 博, 嶋 矢督

広島大学水畜産学部食品工業化学科

\section{On the Peroxidatic Decomposition of Methyl Linoleate Hydroperoxide by Hepato-Catalase}

\author{
Hiroshi Naito, Susumu Shimaya \\ Department of Focd Chemistry and Technology, Hiroshima University, \\ Fukuyama, Hiroshima
}

J. Jap. Soc. Food and Nutr., 24 (5), 284 286 (1971)

In an attempt to investigate enzyme-catalyzing degradation of lipid peroxide in the living body, methyl linoleate hydroperoxide (MLHP) was tested as a substrate for peroxidatic reaction catalyzed by a commercial hepatocatalase (E.C.1.11.1.6.), Caperase.

Autoxidized methyl linoleate was further fractionated on a cellulose-powder column with $n$-hexane then with methanol, and MLHP in the latter eluate was applied on the enzyme assay.

The approximate reaction constant, $\mathrm{k}_{1}$, was calculated from the linear relationship of substrate con. centration and the maximum velocity on the color development of the excess amount of guaiacol as a hydrogen donor.

Although MLHP did not react with the intact enzyme at all, partial alkali-denaturation within the close $\mathrm{pH}$ range between 11.0 and 11.3 made it possible to catalyze the decomposition of both $\mathrm{H}_{2} \mathrm{O}_{2}$ and MLHP at approximately the same rate of the order of $10^{2} \mathrm{sec}^{-1}$, mole $e^{-1}$, with higher value on MLHP than on $\mathrm{H}_{2} \mathrm{O}_{2}$, provided that one mole of hydroperoxide is contained per mole of MLHP.

(Received May 4, 1971)

脂質のハイドロパーオキサイド（L H P ）は各種の栄 盖的女るいは病理的要因によって生体内で生成すること が明らかにされているが、この上5な物質が分解またい 安定化する機模，とくに䤃菜の関与について現在まてにに 十分な知見がえられていない。いっ澡らカタラーゼは水 素供与体の存在で八イドロパーオキサイド $\left(\mathrm{H}_{2} \mathrm{O}_{2}\right.$ もらく めた広義の）を基質としてペルオキシダーゼ（POD） 活性を発現することが知られているが，L H P を基質と して検封した報告が見当らないので本実験をおこなっ た。

\section{害 験 方 法}

1. リノール酸メチルーハイドロパーオキサイド (ML HP) の調製

精製リノール酸メチル尿素複合体(The Holmel Inst.,
U.S. A.)ょり Banks 1)らの方法にしたがって Peroxide Value (P.O. V.) ${ }^{2}$ が約 $1,500 \mathrm{meq} / \mathrm{kg}$ に達するまでn一へ キサン, $85 \%$ メタノール混液中で酸素通気によりハイド ロパーオキサイドの調製をおこない,ついで Kokatnur ${ }^{3)}$ らの方法によりWatman No. 1 粉末ろ紙(Coarse type), または東洋粉末ろ紙(A型，100一200×ッシュ) $2.0 \times 20$ $\mathrm{cm}$ のカラムで四着クロマトグラフをおこない, $n$-ヘキ サン, メタノールの順にそれぞれ未反応画分およびML H P に分画した(第 1 図)。

調製品の一部はP.O.V.; 3,600 （理諭值の $59 \%$ ), $\varepsilon_{232 \mathrm{~m}} \mu ; 14,400$ (第 2 図) をしめした。また赤外線吸収

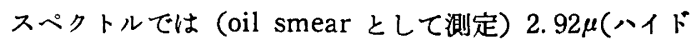

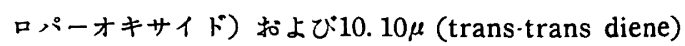
の吸収を碓認した。

\section{2. 酳素}




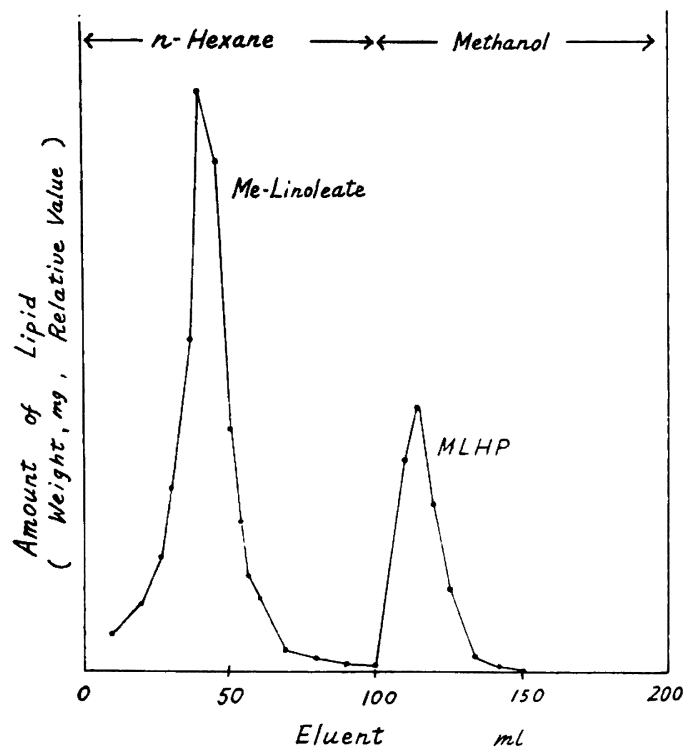

Fig. 1. Absorption chromatography of autoxidized methyl-linoleate on cellulose-powder column. (Watman No.1, $2.0 \times 20 \mathrm{~cm}$ )

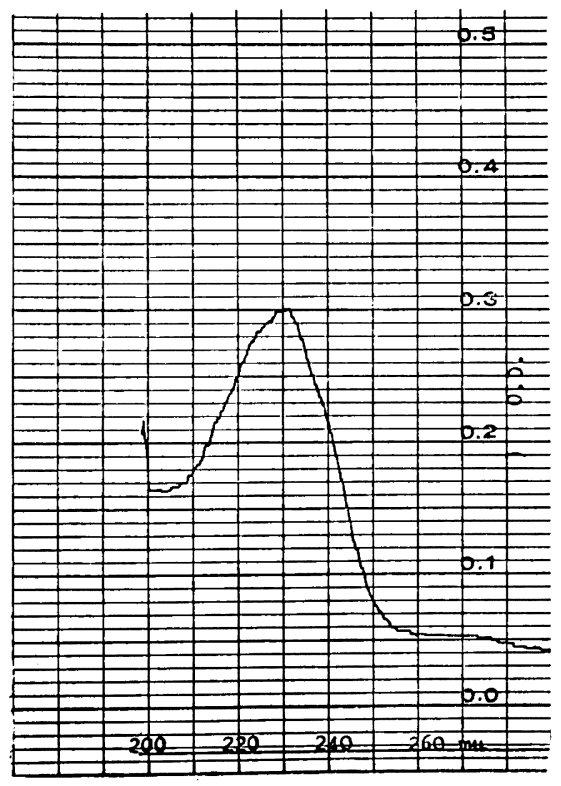

Fig. 2. Ultra-violet absorption spectrum of MLHP in ethanol.

市販のカタラーゼ標品, (Caperase, Molins de Rey, Barucelona, Spain,エーザイ株式会社の提供による)を もちいた。(120 Pevya units/mg.)

\section{POD 活性の测定}

水素供与体としてグアャュールをすちい $470 \mathrm{~m} \mu$ にお
ける発色値から推定しだ)。

すなわち醉素溶液 $(3 \mathrm{mg}) 1.0 \mathrm{~m} l$ とリン酸緩衙液 2.5 $\mathrm{ml}$ を混合し， $0.5 \mathrm{M} \mathrm{KOH}$ で種々の $\mathrm{pH}$ 調整し，室温

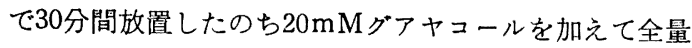

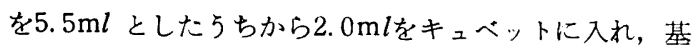
質として $1-7 \times 10^{-2} \mathrm{M} \mathrm{H}_{2} \mathrm{O}_{2}$ または $0.3-0.6 \times 10^{-3} \mathrm{M}$

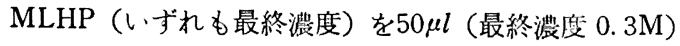
のエタノールに溶解して加え, すみやかにグアヤコール の発色を経時的に測定した。0〜20秒間は扰扰む权直線 的でありここの部分を最大反応速䧹 $\mathrm{V}^{\prime}$ とした。

Hunter゙ににしたかって近似的な速度定数 $\mathrm{k}_{1}$ をもとめ た。 $\left(\mathrm{k}_{1}=(1 /\right.$ 基質〕・蟀素量 $\left.) \times V^{\prime}\right)$ ，ただしテトラグつ ヤコール：基質 $=1: 4$ として計算。

\section{結果}

第3 因にしめすよ5に POD 活性は $\mathrm{pH} 11.0-11.3 の$ せまい範同内で発現し，乞の両側で急激に低下寸るか， MLHP のばあい酸性側でよりゆるやかな減少をしめ した。また第 4 図から明らかなように反灾速度 $\mathrm{V}^{\prime} は \mathrm{H}_{2} \mathrm{O}_{2}$ の濃度に比例しこれょり速度定数 $\mathrm{k}_{1}$ を推定した。

本実駼にもちいたMLHPは反応液中 $0.6 \times 10^{-3} \mathrm{M}$ ょり も高い濃屡では混濁がいちじるしいため測定が不可能で あった。また MLHPは非酳素的にグアヤコールをわず かに発色させるのでブランクとして差引いた。

反応液中に脂質溶凨として加えたエタノールは同時に

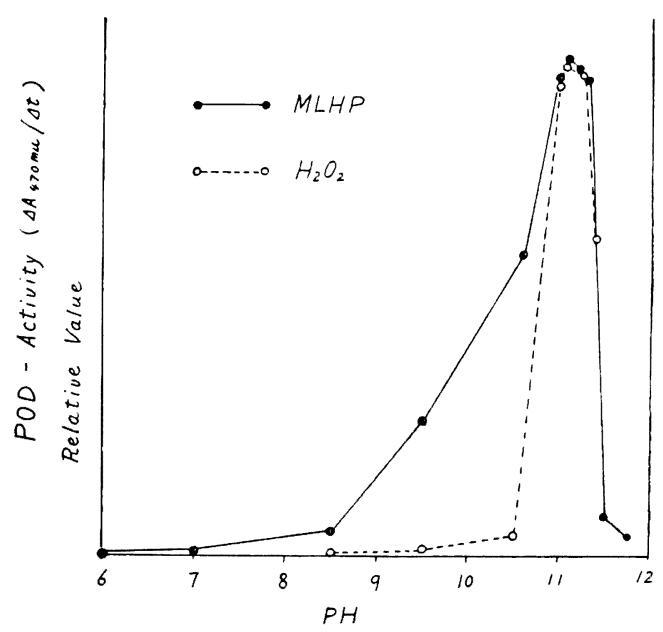

Fig. 3. Effect of $\mathrm{pH}$ on the peroxidase-activity of hepato-catalase.

Reaction mixtures contained in $\mathrm{mM} / 2.5$ $\mathrm{ml}$ : 730 phosphate buffer $(\mathrm{pH}$ was adjus. ted with $0.5 \mathrm{M} \mathrm{KOH}$ ), 0.002 caperase, 6.8 guiacol and $70 \mathrm{H}_{2} \mathrm{O}_{2}$ or MLHP 0.6 in a solution of $50 \mu l$ ethanol. Measurement was carried out from zero to $20 \mathrm{sec}$. immediately after addition of substrate. 


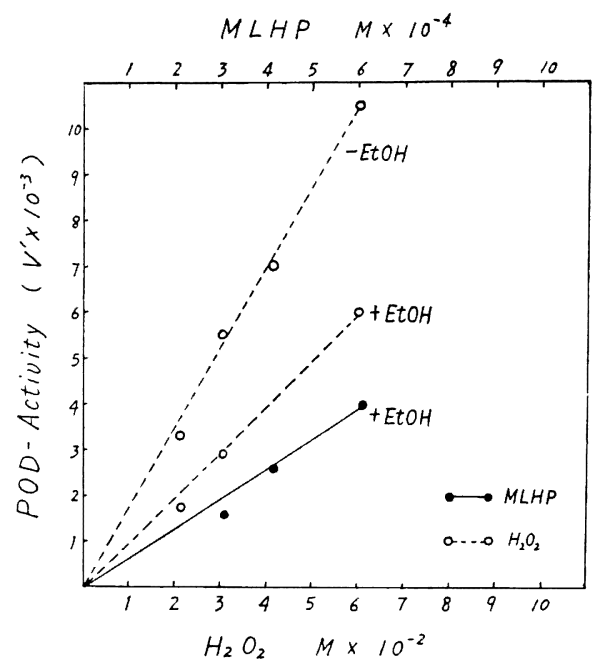

Fig. 4. Peroxidase activity of alkali-denatured hepato-catalase in different substrate concentrations.

Substrate was added after $30 \mathrm{~min}$. preincubation in a room temperature at $\mathrm{pH}$ 11.0-11.3. Details are also shown in the footnote of Fig. 3.

水素供与体であるために無添加区に比較して $\mathrm{V}^{\prime}$ が減少 しているが，第1 表にしめしたよ5にいずれのばあいる Horse raddishペルオキシダーゼ (EC. 1.11.1.7.)のk 1064)にくらべて低い $10^{2}$ の值をしめした。Inada ${ }^{5)} ら$ は牛肝カタラーゼが $\mathrm{pH}$ 11.1飞执いてロイコマラカイト 緑を水素供与体としたばあい $\mathrm{H}_{2} \mathrm{O}_{2}$ に対して $10^{2}$ の値を 報告して扰り，本実歌結果之一致した。

なお MLHP はカタラーゼ反応を全くしめさないが, ペルオキシダーゼ作用に関しては $\mathrm{H}_{2} \mathrm{O}_{2}$ と同䇰であり， むしろやや反応性を高める傾向さえしめした。この結果 は至適 $\mathrm{pH}$ 曲線が両者でややことなっていることと関連 して舆味深い現象と考兄られる。

Table 1. Estimated rate constant of peroxidase-activity of alkali-denatured hepatocatalase

\begin{tabular}{|c|c|c|c|}
\hline Substrate & & $\begin{array}{c}\mathrm{V}^{\prime} \\
\Delta \mathrm{A} 470 \mathrm{~m} \mu / \mathrm{sec} .\end{array}$ & $\mathrm{sec}^{\mathrm{k}} \mathrm{mole}^{-1}$ \\
\hline $\mathrm{H}_{2} \mathrm{O}_{2}$ & $7.0 \times 10^{-2} \mathrm{M}$ & 13. $0 \times 10^{-3}$ & $0.4 \times 10^{2}$ \\
\hline $\begin{array}{l}\mathrm{H}_{2} \mathrm{O}_{2} \\
\quad+0.3 \mathrm{M} \text { ethanol }\end{array}$ & $7.0 \times 10^{-2} \mathrm{M}$ & $6.5 \times 11$ & $0.2 \times 11$ \\
\hline $\begin{array}{l}\text { MLHP } \\
\quad+0.3 \mathrm{M} \text { ethanol }\end{array}$ & $0.6 \times 10^{-3} \mathrm{M}$ & $4.0 \times 11$ & $1.4 \times \prime \prime$ \\
\hline $\begin{array}{l}\mathrm{H}_{2} \mathrm{O}_{2} \\
\quad+0.3 \mathrm{M} \text { ethanol } \\
\quad+1.1 \times 10^{-3} \mathrm{M} \text { Methy } \\
\text { linoleate }\end{array}$ & $\begin{array}{l}7.0 \times 10^{-2} \mathrm{M} \\
\mathrm{yl}\end{array}$ & $5.0 \times 11$ & $0.15 \times 11$ \\
\hline
\end{tabular}

See in the foot-notes of Fig. 3 and Fig. 4.
考 察
以上の実験結果からカタラーゼは $\mathrm{pH} 11.0-11.3$ 1 せ まい籁囲でMLHPを基質としてPOD 活性をしめすこと が明らかである。カタラーゼの POD 活性発現に関して は多くの報告があり, 酸, アルカリ, 各種の蛋白質変性 剤あるいはプロテアーゼ作用などによって醳素の立体構 造が一部解離して，内部のへム部分が露出することによ り基質と結合反応するものと解釈されている6)。

いっぽ5生体内の脂質酸化に関しては多くの研究がな されているが, 細胞の膜成分は多量の不飽和脂肪酸をふ くんでいるので，もし脂質酸化が扰こるものとすればそ の反応は自己触媒的であるために有害な影響をあたえる ことが予想されるが，これに対し種々の安定化要因が考 亲られる。Christophersen") はラット肝臓のグルタチオ ンペルオキシダーゼが GSH を水素供与体としてリノー ル酸ハイドロパーオキサイドを安定なハイドロオキシ化 合物に還元することをしめした。生体内のカタラーゼの 作用機作については現在明らかでないか，离る種の生理 的状態に沶いて POD 活性を発現寸ることはじゅ5ぶん に考えられることである。

MLHP は in vitroでミトコンドリアの酸化的リン酸 化を非共役化するが8)，いっぽ5 Neubert ${ }^{9)}$ はATPで回 復するミトコンドリアの swelling は「収縮因子」によ っても回復し，その主成分はカタラーゼであることを見 出しているが， MLHP のリン脂質酸化を経由したリン 酸化非共役に対してカタラーゼがその POD 活性の発現 によって阻止する可能性が示唆される。

\section{文献}

1) Banks, A., Fazakerley, S., Keay, J. N. and Smith, J. G. M. : J. Sci. Food Agric., 12, 724 (1961)

2) Olcot, H. S. and Doler, O. A.: Proc. Soc. Exp. Biol.Med., 114, 820 (1963)

3) Kokatnur, M. G., Bergan, J. G. and Draper, H. H. : Anal. Biochem., 12, 325(1965)

4) Hunter, M. J.,: (Colowick, S. P. and Kaplan, N. O.,ed.) Method in Enzy. mol., 2, 770 (1955), Acad. Press.

5 ) Inada, Y., Kurozumi, T.and Shibata, K.: J. Biochem., 46, 155, 1101(1959)

6 ）满田久輝 : 蛋白質・核酸·酵素, 8, (11), 83 (1963)

7) Christophersen, B. O.: Biochim. Biophys. Acta, 164, 35 (1968)

8 ) Naito, H., Johnson, B. and Connor Johnson, B.: Proc. Soc. Exp. Biol. Med., 122, 545 (1966)

9) Neubert, D.,: (Tager J. M., Papa, S., Quagliarcillo, E. and Slater, E. C., ed.) Regulation of Metabolic Proce. sses in Mitochondria, 359, (1966), Elsevier Pub. Co.

（昭和46年 5 月 4 日受理） 